\title{
Lip and Oral Cavity Cancer Pathologic TNM Finding v8
}

National Cancer Institute

\section{Source}

National Cancer Institute. Lip and Oral Cavity Cancer Pathologic TNM Finding v8. NCI

Thesaurus. Code C132690.

A pathologic finding about one or more characteristics of lip and oral cavity cancer, following the rules of the TNM AJCC v8 classification system. The pathologic staging is determined after the complete resection of the primary site and/or regional nodal dissection, followed by pathologic examination of the resected specimen(s). (from AJCC 8th Ed.) 